\title{
ВОЗРАСТНАЯ ДИНАМИКА СВОБОДНЫХ АМИНОКИСЛОТ В ТКАНЯХ МЕДИЦИНСКОЙ ПИЯВКИ (Hirudo verbana Carena, 1820) ПРИ ИСКУССТВЕННОМ ВОСПРОИЗВОДСТВЕ В АКВАКУЛЬТУРЕ
}

\author{
Л.А. КОВАЛЬЧУК 1 ${ }^{\bowtie}$, Л.В. ЧЕРНАЯ1, Н.В. МИКШЕВИЧ 2
}

Медицинские пиявки (в том числе Hirudo verbana Carena, 1820) используемые в ветеринарии, медицине и фармакологии, в настоящее время выращиваются в искусственно созданных условиях на биофабриках. Технология гирудокультуры как составляющая биотехники аквакультуры основана на методе ускоренного роста и развития пиявок при интенсивном вскармливании, что позволяет получить качественную продукцию в достаточно короткие сроки (8-10 мес). При этом проблема оценки физиологического статуса выращенных особей в условиях искусственного воспроизводства остается не до конца решенной. Нами впервые представлены результаты, подтверждающие возможность использования данных о возрастной специфике аминокислотного состава тканей при оценке физиологического состояния и благополучия медицинской пиявки в природе и в аквакультуре. Цель работы - изучение содержания свободных аминокислот в тканях медицинских пиявок при искусственном воспроизводстве в аквакультуре в зависимости от возраста. Исследования проводили в 2012 году на особях аптечной пиявки без признаков заболевания, приобретенных на биофабрике «Международный центр медицинской пиявки» (Московская обл., п. Удельная). Пиявок содержали в лаборатории в стеклянных сосудах с дехлорированной водой при температуре $20-22{ }^{\circ} \mathrm{C}$ и один раз в месяц кормили свежей бычьей кровью, полученной от здоровых животных. Возраст экспериментальных особей $H$. verbana составлял 5 сут (новорожденные нитчатки, 0+ мес), 1, 3, 5, 7 и 9 мес, средняя масса тела - соответственно 0,029; 0,09; 0,25; 0,61; 1,33 и 1,81 г. Контролем служили новорожденные особи. Концентрацию свободных аминокислот (АК) в кожно-мышечной ткани определяли на анализаторе АAA-339M («Mikrotechna», Чехия). Всего было использовано 105 особей пиявок, подготовлено 30 биопроб, выполнено 660 элементоопределений. Рассчитывали суммарный фонд метаболических групп АК: заменимых (ЗАК) - аланин, аспарагиновая кислота, глицин, глутаминовая кислота + глутамин, пролин, серин, тирозин, цистеин; незаменимых (НАК) - аргинин, валин, гистидин, изолейцин, лейцин, лизин, метионин, треонин, триптофан, фенилаланин; с разветвленной углеродной цепью (АКРУЦ) - валин, изолейцин, лейцин; ароматических (АРАК) - тирозин, фенилаланин; серосодержащих (ССАК) - метионин, цистеин, цистеиновая кислота. Показано, что аминокислотный состав тканей $H$. verbana был представлен 23 АК и их дериватами. Вне зависимости от возраста пиявок доминирующими АК с антиоксидантными свойствами были глутамин и глутаминовая кислота, аланин, валин, лейцин, глицин, суммарное содержание которых составляло у нитчаток $65 \%$, 9-месячных особей $-58 \%$ от общего пула АК. В тканях у медицинских пиявок, как и у теплокровных животных, был выявлен полный состав незаменимых аминокислот: треонин, валин, лизин, лейцин, изолейцин, гистидин, аргинин, метионин, фенилаланин, триптофан. С возрастом уменьшались суммарные концентрации свободных аминокислот $(r=-0,98$ при $p=0,000)$, что было обусловлено резким снижением содержания аргинина (в 24,0 раза), пролина (в 13,4 раза), изолейцина (в 12,2 раза), глицина (в 8,5 раза), лизина (в 6,8 раза), гистидина (в 6,6 раза), лейцина (в 5,2 раза), орнитина (в 4,0 раза), глутаминовой кислоты и глутамина (в 3,8 раза), аланина (в 2,9 раза). В возрасте 5,7 и 9 мес у пиявок отмечали полный расход вторичных метаболитов (таурина, цитруллина и триптофана) $($ р $<0,001)$. Однако аминокислотный баланс азотистого и белкового обмена не нарушался, поскольку соотношение незаменимые/заменимые АК существенно не менялось, и его величина составляла 0,60 у нитчаток, 0,73у 9-месячных пиявок. Установлено, что рост и развитие $H$. verbana сопровождались снижением величины индикатора зрелости (соотношение глицин/аланин) - с 0,75 у нитчаток до 0,25 у пиявок в возрасте 9 мес. Имеющиеся в литературе сведения и данные наших исследований дают основание полагать, что функциональные аминокислоты могут использоваться в качестве биомаркеров при разработке технологий промышленного разведения этих амфибионтов.

Ключевые слова: медицинские пиявки, гирудокультура, свободные аминокислоты, возраст, физиологический статус.

Одна из задач аквакультуры как интенсивно развивающейся отрасли сельского хозяйства - оценка физиологических особенностей и потребностей гидробионтов на разных этапах онтогенеза при искусственном воспроизводстве. Поиск критериев благополучия объектов аквакультуры тесно

* Работа выполнена в рамках государственного задания Института экологии растений и животных УрО РАН и частично поддержана грантом Президиума РАН «Фундаментальные науки - медицине» 12-П-4-1049. 
связан с проблемой адаптации организма к условиям внешней среды. Для оперативной оценки экологической безопасности и создания достаточных условий для устойчивого развития гидробионтов требуются надежные технологии диагностики физиологического состояния животных и среды их обитания, такие как эколого-физиологические биомаркеры $(1,2)$. Важную задачу представляет разработка и совершенствование биомаркеров по иммунологическим, гистопатологическим и физиологическим параметрам гидробионтов, а также применение таких маркеров в практике искусственного воспроизводства.

Данные, опубликованные в научной литературе, и результаты наших исследований позволяют выдвинуть концепцию биомаркеров на базе функциональных аминокислот (АК), обладающих широким спектром метаболической активности и играющих важную роль в энергетическом и пластическом обмене у животных (3-5). Так, при сравнении биохимического состава 182 пресноводных и морских видов зоопланктона показано, что пресноводные виды характеризуются более низким количеством АТФ и свободных аминокислот и более высоким содержанием РНК (6). Ряд работ посвящен исследованию метаболизма веслоногих рачков, планктонных копепод и дафний $(7,8)$. Биологическая роль свободных аминокислот и их дериватов в метаболизме морских беспозвоночных показана в исследованиях мышечных белков двустворчатых моллюсков (9). Выявлен высокий аминокислотный метаболизм в тканях у черноморского моллюска-вселенца Anadara kagoshimensis, который обеспечивает адаптивную устойчивость вида к новым условиям среды (10). Представлены данные по трофической специфике аминокислотного состава тканей пресноводных пиявок, а также показана ключевая роль незаменимых аминокислот в процессах адаптации кровососущих гирудинид к обитанию в экстремальных климатических условиях $(11,12)$.

Возрастная динамика свободных АК и их производных в тканях животных может служить информативным показателем физиологического статуса растущего организма, что особенно актуально при массовом воспроизводстве в условиях высокой плотности особей (13-15). Отмечены изменения аминокислотного профиля и роль свободных АК в период личиночного развития камбалы Platichthys stellatus (16). Выявлено высокое содержание незаменимых аминокислот в организме у пресноводного неотропического вида рыб Piaractus mesopotamicus в период раннего онтогенеза и показана роль таурина в регуляции осмоляльности жидкости (15). Имеются данные о сезонной вариативности метаболически инертного таурина в мышцах макрели, обитающей в водах Китайского моря (17). Установлено, что аминокислотный состав промысловых рыб коррелирует с характером их питания (18). Исследована реорганизация азотистого метаболизма и роль свободных аминокислот в механизмах низкотемпературной адаптации на примере эвритермной сорной рыбы ротана Perccottus glehni (19). Эти данные подтверждают важность участия свободных аминокислот в регуляции ключевых метаболических процессов, направленных на поддержание устойчивого существования пресноводных гидробионтов в природно-антропогенных условиях экосистем.

Медицинских пиявок для использования в медицинской, ветеринарной и фармацевтической практике выращивают на биофабриках в искусственно созданных условиях $(20,21)$. Современная технология аквакультуры пиявок (гирудокультура) базируется на методике, разработанной отечественными учеными еще в середине XX века. Ее основные этапы - спаривание маточного поголовья пиявок, выборка молоди из созревших коконов и ее ускоренное раскармливание говяжьей кровью до размеров готовой 
продукции $(22,23)$. Процессы ускоренного роста и развития пиявок в гирудокультуре связаны исключительно с условиями выращивания на биофабриках, что сопряжено с воздействием ряда специфических факторов (частая смена воды, высокая плотность популяции, пространственное ограничение и т.д.), которые отражаются на физиологическом статусе особей и становятся причиной высокой смертности молоди. При этом проблема оценки благополучия выращенных особей в условиях искусственного воспроизводства остается не до конца решенной, а исследованиям аминокислотного обмена аннелид (медицинских пиявок) в мировой литературе не уделено должного внимания. Использование оптимального соотношения жизненно важных свободных АК в тканях медицинских пиявок как критерия благополучия может способствовать эффективному и качественному воспроизводству этих ценных гидробионтов в гирудокультуре.

Нами впервые представлены результаты, подтверждающие возможность использования данных о возрастной специфике аминокислотного состава тканей при оценке физиологического состояния и благополучия медицинской пиявки в природе и в аквакультуре.

Цель работы - изучение содержания свободных аминокислот в тканях медицинских пиявок при искусственном воспроизводстве в аквакультуре в зависимости от возраста.

Методика. Исследования проводили в 2012 году на особях аптечной пиявки (Hirudo verbana Carena, 1820) без признаков заболевания, приобретенных на биофабрике «Международный центр медицинской пиявки» (Московская обл., п. Удельная). Пиявок содержали в лаборатории в стеклянных сосудах с дехлорированной водой при температуре $20-22{ }^{\circ} \mathrm{C}$ и один раз в месяц кормили свежей бычьей кровью, полученной от здоровых животных. Возраст экспериментальных особей $H$. verbana составлял 5 сут (новорожденные нитчатки, 0+ мес), 1, 3, 5, 7 и 9 мес, средняя масса тела - соответственно 0,$029 ; 0,09 ; 0,25 ; 0,61 ; 1,33$ и 1,81 г. Контролем служили новорожденные особи. При проведении исследований руководствовались рекомендациями Европейской Конвенции по защите животных $(24,25)$.

Концентрацию свободных АК в кожно-мышечной ткани пиявок определяли на анализаторе AАA-339M («Mikrotechna», Чехия). Для этого 1 г сырой ткани гомогенизировали в 3 мл фосфатного буфера $(\mathrm{pH} \mathrm{7,4).}$ Двухступенчатое центрифугирование гомогенатов проводили на рефрижераторной центрифуге K-23D («MLW», Германия) в течение 15 мин при 10000 об/мин и 30 мин при 8000 об/мин. Для депротеинизации добавляли 0,1 мл $30 \%$ сульфосалициловой кислоты, для нейтрализации кислой реакции раствора - 0,2 мл 7 \% гидрооксида лития. В качестве внутреннего стандарта использовали норлейцин $(0,1$ мл). Рассчитывали суммарный фонд метаболических групп АК: заменимых (ЗАК) - аланин, аспарагиновая кислота, глицин, глутаминовая кислота + глутамин, пролин, серин, тирозин, цистеин; незаменимых (НАК) - аргинин, валин, гистидин, изолейцин, лейцин, лизин, метионин, треонин, триптофан, фенилаланин; с разветвленной углеродной цепью (АКРУЦ) - валин, изолейцин, лейцин; ароматических (АРАК) - тирозин, фенилаланин; серосодержащих (ССАК) - метионин, цистеин, цистеиновая кислота. Всего было использовано 105 особей пиявок, подготовлено 30 биопроб, выполнено 660 элементоопределений.

Для статистической обработки данных использовали стандартные пакеты компьютерных программ Microsoft Excel 2007 и STATISTICA 7.0 («StatSoft, Inc.», США). Рассчитывали средние значения (M) и стандартные ошибки средних ( $\pm \mathrm{SEM})$, в дальнейшем исходные данные преобразовывали 
в логарифмическую (мкмоль/100 г) или арксинусную (\% от фонда АК) формы. При множественном сравнении данных использовали $F$-критерий Фишера, различия с контролем оценивали тестом Даннета (ANOVA). Kopреляционные связи между содержанием свободных АК в тканях пиявок и их возрастом определяли с помощью коэффициента корреляции $r$. Визуализация полученных результатов была реализована методом главных компонент (РСA) в статистической среде R ( R 3.1.2, пакеты «Vegan» и «Ade4») (26). Различия считали статистически значимыми при $\mathrm{p}<0,05$.

Результаты. Аминокислотный состав тканей медицинской пиявки H. verbana был представлен 23 АК и их дериватами. У исследованных особей, как и у теплокровных животных $(1,2)$, присутствовал полный набор функционально значимых незаменимых аминокислот: треонин, валин, лизин, лейцин, изолейцин, гистидин, аргинин, метионин, фенилаланин, триптофан. Доминирующими АК с антиоксидантной направленностью, вне зависимости от возраста, были глутамин и глутаминовая кислота, аланин, валин, лейцин, глицин, суммарное содержание которых у контрольных особей (нитчаток) составляло $65 \%$, у 9-месячных особей - $58 \%$ от общего фонда АК.

Наибольшие показатели аминокислотного обмена были характерны для молоди пиявок на самых ранних этапах развития (табл. 1). Так, суммарные концентрации свободных АК в тканях новорожденных и 1-месячных особей не показали статистически значимых различий (p > 0,05), несмотря на кратное увеличение массы тела последних в результате начала интенсивного кормления. В тканях $H$. verbana наблюдалось линейное падение суммарных концентраций свободных АK $(r=-0,98$ при $\mathrm{p}=0,000)$. В процессе ускоренного роста и развития у взрослых пиявок (9 мес) в сравнении с контрольными особями отмечали 3-кратное снижение суммарного фонда AK $(\mathrm{p}<0,001)$.

На ранних этапах онтогенеза у пиявок наблюдалась высокая потребность в аминокислотах, регулирующих интенсивное возрастание мышечной массы (валин, аланин, орнитин, аргинин) и принимающих участие в репродуктивных функциях (глутамин, лизин, гистидин, орнитин, лизин), образовании основного белка соединительной ткани коллагена и эластина (аланин, глицин, лизин, пролин, валин, лейцин, треонин), детоксикации продуктов межуточного обмена (глицин, глутаминовая кислота, цистеин, триптофан), нормализации углеводного и липидного обмена и формировании иммунитета (аланин, таурин, гистидин, лейцин).

Наиболее существенные возрастные различия $(F 5,24>147,74$ при $\mathrm{p}<0,001)$ были показаны для аминокислот, стимулирующих в организме важнейшие физиологические процессы. Так, с возрастом в тканях $H$. verbana резко уменьшалось содержание аргинина (в 24,0 раза), пролина (в 13,4 раза), изолейцина (в 12,2 раза), глицина (в 8,5 раза), лизина (в 6,8 раза), гистидина (в 6,6 раза), лейцина (в 5,2 раза), орнитина (в 4,0 раза), глутаминовой кислоты и глутамина (в 3,8 раза), а также аланина (в 2,9 раза) $(\mathrm{p}<0,001)$ (см. табл. 1).

Важно отметить полный расход вторичных метаболитов (таурина, цитруллина и триптофана) у пиявок в возрасте 5, 7 и 9 мес (р < 0,001). В гирудокультуре онтогенез пиявок также был обусловлен высокой обеспеченностью тканей метаболическими группами АK: с разветвленной углеродной цепью (валин, лейцин, изолейцин), защищающими мышечные волокна от окисления и деструкции; ароматическими (фенилаланин, тирозин), участвующими в синтезе биогенных аминов и нейромедиаторов; серосодержащими (цистеиновая кислота, цистеин, метионин), обладающими 
1. Содержание (мкмоль/100 г) свободных аминокислот в тканях медицинской пиявки Hirudo verbana Carena, 1820 при искусственном выращивании в гирудокультуре в зависимости от возраста $(n=30, M \pm \mathrm{SEM})$

\begin{tabular}{|c|c|c|c|c|c|c|c|c|}
\hline \multirow[b]{2}{*}{ Аминокислота } & \multicolumn{6}{|c|}{ Возраст, мес } & \multicolumn{2}{|c|}{ ANOVA } \\
\hline & $\begin{array}{c}0+, \\
\text { контроль }\end{array}$ & 1 & 3 & 5 & 7 & 9 & $F 5,24$ & $\mathrm{p}$ \\
\hline Цистеиновая кислота & $49,24 \pm 0,49$ & $79,64 \pm 0,64$ & $54,48 \pm 1,44 \mathrm{NS}$ & $46,25 \pm 1,68^{\mathrm{NS}}$ & $41,28 \pm 1,24$ & $31,98 \pm 1,02$ & 140,67 & 0,000 \\
\hline Таурин & $11,65 \pm 0,36$ & $9,39 \pm 0,51$ & $6,46 \pm 0,50$ & Следы & Следы & Следы & 1201,90 & 0,000 \\
\hline Аспарагиновая кислота & $9,95 \pm 0,41$ & $126,62 \pm 1,92$ & $85,01 \pm 4,27$ & $16,07 \pm 1,07$ & $4,65 \pm 0,44$ & $4,86 \pm 0,47$ & 521,48 & 0,000 \\
\hline Треонин & $81,88 \pm 1,20$ & $96,20 \pm 1,68$ & $58,17 \pm 0,85$ & $77,60 \pm 3,38^{\mathrm{NS}}$ & $98,23 \pm 3,66$ & $73,40 \pm 2,56^{\mathrm{NS}}$ & 42,45 & 0,000 \\
\hline Серин & $91,20 \pm 2,86$ & $48,47 \pm 1,09$ & $87,78 \pm 1,57^{\mathrm{NS}}$ & $94,49 \pm 3,50^{\mathrm{NS}}$ & $104,02 \pm 1,22$ & $76,03 \pm 2,93$ & 93,99 & 0,000 \\
\hline Глутамат + глутамин & $608,20 \pm 5,79$ & $413,89 \pm 2,62$ & $381,01 \pm 3,08$ & $285,49 \pm 6,89$ & $203,07 \pm 1,36$ & $158,33 \pm 3,17$ & 1201,5 & 0,000 \\
\hline Пролин & $70,74 \pm 1,06$ & $28,62 \pm 1,00$ & $14,12 \pm 0,71$ & $9,48 \pm 0,97$ & $7,07 \pm 0,43$ & $5,28 \pm 0,56$ & 206,85 & 0,000 \\
\hline Глицин & $157,01 \pm 2,10$ & $208,32 \pm 2,27$ & $134,16 \pm 1,60^{\mathrm{NS}}$ & $77,47 \pm 3,24$ & $27,11 \pm 0,58$ & $18,47 \pm 1,32$ & 147,75 & 0,000 \\
\hline Аланин & $209,13 \pm 1,74$ & $236,69 \pm 1,52$ & $205,97 \pm 1,54 \mathrm{NS}$ & $130,04 \pm 3,38$ & $97,86 \pm 1,61$ & $73,27 \pm 2,62$ & 569,51 & 0,000 \\
\hline Цитруллин & $9,15 \pm 0,42$ & $9,37 \pm 0,42^{\mathrm{NS}}$ & $4,72 \pm 0,35$ & Следы & Следы & Следы & 1189,60 & 0,000 \\
\hline Валин & $93,31 \pm 0,85$ & $110,19 \pm 1,50$ & $73,09 \pm 1,54$ & $96,47 \pm 3,30^{\mathrm{NS}}$ & $121,77 \pm 1,46$ & $91,32 \pm 2,12^{\mathrm{NS}}$ & 71,53 & 0,000 \\
\hline Цистеин & $6,37 \pm 0,42$ & $4,12 \pm 0,17$ & $23,55 \pm 0,85$ & $15,32 \pm 0,71$ & $8,52 \pm 0,50$ & $6,35 \pm 0,46^{\mathrm{NS}}$ & 142,80 & 0,000 \\
\hline Метионин & $23,56 \pm 0,84$ & $14,80 \pm 0,43$ & $53,29 \pm 1,48$ & $36,58 \pm 3,40$ & $22,99 \pm 0,62^{\mathrm{NS}}$ & $18,95 \pm 0,56$ & 93,91 & 0,000 \\
\hline Изолейцин & $121,31 \pm 1,40$ & $98,36 \pm 1,79^{\mathrm{NS}}$ & $34,51 \pm 0,68$ & $23,90 \pm 2,99$ & $13,14 \pm 0,72$ & $9,98 \pm 0,67$ & 263,72 & 0,000 \\
\hline Лейцин & $180,72 \pm 2,49$ & $154,04 \pm 1,39$ & $130,88 \pm 2,61$ & $86,36 \pm 3,67$ & $46,1 \pm 0,95$ & $34,67 \pm 0,62$ & 840,56 & 0,000 \\
\hline Тирозин & $15,44 \pm 0,76$ & $8,80 \pm 0,71$ & $27,51 \pm 1,12$ & $20,41 \pm 1,73^{\mathrm{NS}}$ & $16,11 \pm 0,60^{\mathrm{NS}}$ & $11,77 \pm 0,80^{\mathrm{NS}}$ & 40,30 & 0,000 \\
\hline Фенилаланин & $30,87 \pm 1,40$ & $34,9 \pm 0,54 \mathrm{NS}$ & $56,34 \pm 1,11$ & $41,87 \pm 2,62$ & $23,76 \pm 0,44$ & $17,83 \pm 0,81$ & 107,67 & 0,000 \\
\hline
\end{tabular}




\begin{tabular}{|c|c|c|c|c|c|c|c|c|}
\hline & & & & & & & \multicolumn{2}{|c|}{ Продолжкение таблицы } \\
\hline Триптофан & $2,82 \pm 0,19$ & $22,71 \pm 0,77$ & $5,53 \pm 0,33$ & Следы & Следы & Следы & 1659,40 & 0,000 \\
\hline Орнитин & $27,43 \pm 0,89$ & $27,12 \pm 1,01^{\mathrm{NS}}$ & $29,20 \pm 0,49^{\mathrm{NS}}$ & $18,48 \pm 1,00$ & $9,15 \pm 0,51$ & $6,82 \pm 0,49$ & 176,12 & 0,000 \\
\hline Лизин & $70,39 \pm 1,49$ & $79,41 \pm 1,63^{\mathrm{NS}}$ & $79,29 \pm 1,01^{\mathrm{NS}}$ & $45,46 \pm 2,09$ & $13,96 \pm 0,54$ & $10,35 \pm 0,82$ & 479,28 & 0,000 \\
\hline Гистидин & $1,19 \pm 0,02$ & $4,68 \pm 0,42$ & $11,77 \pm 0,43$ & $3,86 \pm 0,07$ & $0,89 \pm 0,06^{\mathrm{NS}}$ & $0,18 \pm 0,01$ & 572,90 & 0,000 \\
\hline Аргинин & $46,98 \pm 1,08$ & $31,17 \pm 0,77$ & $22,93 \pm 0,66$ & $14,43 \pm 1,09$ & $7,72 \pm 0,51$ & $1,96 \pm 0,07$ & 551,75 & 0,000 \\
\hline Фонд АК & $1918,51 \pm 26,98$ & $1847,58 \pm 23,72^{\mathrm{NS}}$ & $1579,74 \pm 26,41$ & $1140,04 \pm 42,57$ & $867,37 \pm 13,74$ & $650,80 \pm 12,60$ & 418,82 & 0,000 \\
\hline HAK & $653,02 \pm 10,66$ & $646,52 \pm 10,54 \mathrm{NS}$ & $525,80 \pm 10,71$ & $426,53 \pm 19,98$ & $348,56 \pm 8,96$ & $258,64 \pm 8,24$ & 203,22 & 0,000 \\
\hline 3AK & $1168,02 \pm 21,23$ & $1075,54 \pm 10,83^{\mathrm{NS}}$ & $959,10 \pm 14,01$ & $648,79 \pm 20,97$ & $468,37 \pm 6,50$ & $354,36 \pm 7,29$ & 611,56 & 0,000 \\
\hline АКРУЦ & $395,33 \pm 4,66$ & $362,59 \pm 4,51$ & $238,48 \pm 4,83$ & $206,73 \pm 9,20$ & $181,02 \pm 2,93$ & $135,97 \pm 2,09$ & 316,78 & 0,000 \\
\hline APAK & $49,13 \pm 2,32$ & $66,49 \pm 1,96$ & $89,38 \pm 2,52$ & $62,29 \pm 3,84$ & $39,83 \pm 1,01$ & $29,61 \pm 0,48$ & 101,66 & 0,000 \\
\hline CCAK & $90,83 \pm 1,45$ & $107,94 \pm 1,65$ & $137,78 \pm 4,20$ & $98,15 \pm 5,58^{\mathrm{NS}}$ & $72,79 \pm 2,35$ & $56,28 \pm 0,31$ & 99,47 & 0,000 \\
\hline HAK/ЗАК & 0,60 & 0,60 & 0,60 & 0,66 & 0,74 & 0,73 & & \\
\hline ИЗ (глицин/аланин) & 0,75 & 0,88 & 0,65 & 0,60 & 0,28 & 0,25 & & \\
\hline
\end{tabular}

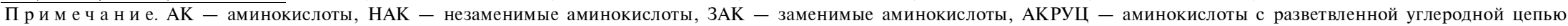

АРАК - ароматические аминокислоты, ССАК - серосодержащие аминокислоты, ИЗ - индикатор зрелости.

NS Статистические различия с контролем отсутствуют (при $\mathrm{p}>0,05$ ). 
иммуномодулирующими и детоксицирующими свойствами (см. табл. 1).

Баланс азотистого и белкового обмена характеризовал коэффициент отношения незаменимых АК к заменимым, который как у контрольных особей $(\mathrm{HAK} / 3 \mathrm{AK}=0,60)$, так и у 9-месячных пиявок $(\mathrm{HAK} / 3 \mathrm{AK}=0,73)$ существенно не менялся (см. табл. 1). Важно отметить, что для индикатора зрелости (ИЗ, коэффициент отношения глицина к аланину) наблюдали обратную картину - уменьшение значений от 0,75 (нитчатки) до 0,25 (9 мес). Известно, что у промысловых видов рыб возрастание содержания аланина и снижение количества глицина в тканях с возрастом служит устойчивым признаком, поэтому соотношение аланин/глицин можно использовать в качестве индикатора зрелости: значения ИЗ, равные 1,2-1,4, соответствуют неполовозрелым особям, 0,3-0,6 - зрелым (27). Согласно нашим данным, показатель ИЗ, используемый для диагностики половой зрелости рыб, может быть эффективен и при оценке возрастных особенностей пиявок в гирудокультуре.



Рис. 1. Процентное содержание метаболических групा аминокислот в тканях медицинской пиявки Hirudo verbana Carena, 1820 при искусственном выращивании в гирудокультуре в зависимости от возраста: 1 - заменимые, 2 - незаменимые, 3 - с разветвленной углеродной цепью, 4 ароматические, 5- серосодержащие $(n=30, M \pm \mathrm{SEM})$.

Мы выявили статистически значимые корреляционные связи между возрастом медицинских пиявок и процентным содержанием (\% от суммарного фонда АК) в их тканях для большинства свободных АК и основных метаболических групп (рис. 1).

Так, рост и развитие $H$. verbana в течение 9 мес сопровождались значительным повышением в тканях процентного содержания валина, метионина, серина, тирозина, треонина, цистеиновой кислоты, цистеина, фенилаланина $(r=0,55-0,90)$, а также суммарного фонда НАК $(r=0,86)$, АРАК

$(r=0,60)$ и ССАК $(r=0,83)(\mathrm{p}<0,05)$. Вместе с тем по мере роста пиявок в их тканях наблюдалось существенное снижение процентного содержания аргинина, аспарагиновой кислоты, глицина, глутамата и глутамина, изолейцина, лейцина, лизина, орнитина, пролина, таурина, триптофана, цитруллина (коэффициенты корреляции $r$ составили от $-0,38$ до $-0,96$ ) и пула ЗАК $(r=-0,85)($ р $<0,05)$. Возрастная специфика содержания аминокислот $(\%$ от фонда) в тканях $H$. verbana наглядно представлена при использовании метода главных компонент (рис. 2, табл. 2). На рисунке 2 приведена пространственная дифференциация исследованных возрастных групп медицинских пиявок согласно их физиологическим потребностям в отдельных аминокислотах, причем для 7- и 9-месячных особей наблюдалась очевидная 
С первой главной компонентой (PC1, 58,89 \% общей дисперсии данных), тесно коррелировали аминокислоты, вклад которых в возрастные различия превышал 6,02 \% общей дисперсии, - таурин, треонин, серин, глицин, цитруллин, валин, лейцин, аргинин ( $<<0,001)$. Наибольший вклад во вторую главную компоненту (РС2, 23,36 \% общей дисперсии данных) вносили аспарагиновая кислота, пролин, аланин, цистеин, фенилаланин, орнитин, гистидин ( $<0,001)$ (см. рис. 2, табл. 2), для процентного содержания которых в тканях пиявок была характерна невысокая возрастная вариабельность.

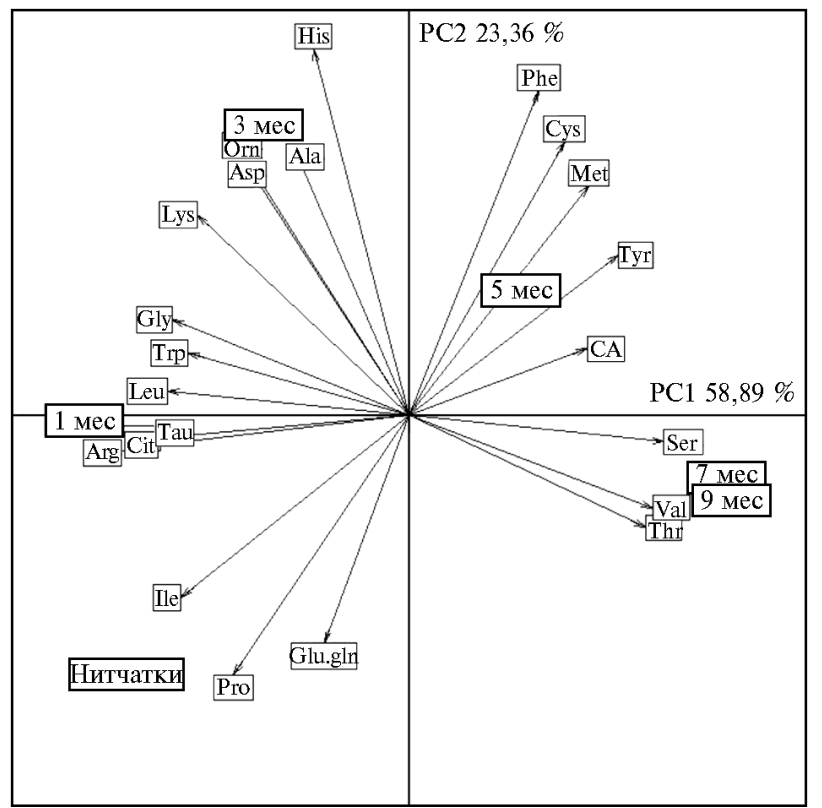

Рис. 2. Возрастная специфика аминокислотного состава тканей медицинской пиявки Hirudo verbana Carena, 1820 при искусственном выращивании в гирудокультуре в пространстве главных компонент: CA - цистеиновая кислота, Tau - таурин, Asp - аспарагиновая кислота, Thr треонин, Ser - серин, Glu.gln - глутаминовая кислота и глутамин, Pro - пролин, Gly глицин, Ala - аланин, Cit - цитруллин, Val - валин, Сys - цистеин, Met - метионин, Ile - изолейцин, Leu - лейцин, Tyr - тирозин, Phe - фенилаланин, Trp - триптофан, Orn - орнитин, Lys - лизин, His - гистидин, Arg - аргинин. Стрелками отмечены корреляции аминокислот с главными компонентами $(n=30)$.

В нашей работе выявлена роль увеличенного пула аминокислот, участвующих в регуляции обменных процессов с антиоксидантной направленностью, за счет которого возрастает устойчивость организма к гипоксии и поддерживается антитоксический эффект в период 5-месячного роста и развития. На ранних этапах онтогенеза высокая активность аминокислотного метаболизма установлена и для других представителей водных организмов, таких как моллюск Corbicula japonica, звездчатая камбала Platichthys stellatus и пресноводная лучеперая рыба Piaractus mesopotamicus $(9,15,16)$.

Обращает на себя внимание высокая изменчивость концентрации заменимых и эссенциальных АК, обусловленная повышенными потребностями в углеводном, липидном обмене и в синтезе белка в период активного роста и развития пиявок. Это согласуется с имеющимися сведениями как для планктонных видов копепод, у которых с возрастом существенно изменяется аминокислотный состав тканей с одновременным повышением содержания тирозина, участвующего в синтезе гормонов (8), так и для 
медицинских пиявок. Высокая потребность в незаменимых аминокислотах и таурине отмечена для мальков пресноводной лучеперой рыбы Piaractus mesopotamicus (15). У личинок звездчатой камбалы Platichthys stellatus в сравнении с половозрелыми особями выявлено более высокое содержание лейцина и изолейцина (16). У моллюсков Corbicula japonica, используемых для промышленного производства биологически активных пищевых добавок, количество свободных аминокислот существенно зависит от стадии развития особей, при этом, как и у медицинских пиявок, доминирующей аминокислотой в тканях на всех этапах биологического цикла выступает глутаминовая кислота, играющая ключевую роль в азотистом обмене (9).

2. Результаты компонентного анализа содержания свободных аминокислот (\% от суммарного фонда) в тканях медицинской пиявки Hirudo verbana Carena, 1820 различных возрастных групп при искусственном выращивании в гирудокультуре $(n=30)$

\begin{tabular}{|c|c|c|c|c|}
\hline \multirow{2}{*}{$\begin{array}{c}\text { Аминокислота } \\
(i=22)\end{array}$} & \multicolumn{2}{|c|}{$\begin{array}{c}\text { Нагрузки } \\
\text { (loadings, aij) }\end{array}$} & \multicolumn{2}{|c|}{$\begin{array}{l}\text { Вклад в главную компоненту } \\
\left.\text { (contribution }=\left(\mathrm{a}^{2} \mathrm{ij} * 100\right) / \lambda_{\mathrm{j}}, \%\right)\end{array}$} \\
\hline & 1 & 2 & 1 & 2 \\
\hline Цистеиновая кислота & $0,70^{* * *}$ & 0,16 & 3,81 & 0,52 \\
\hline Таурин & $-0,95^{* * *}$ & $-0,05$ & 6,98 & 0,04 \\
\hline Аспарагиновая кислота & $-0,58^{* * *}$ & $0,63^{* * *}$ & 2,63 & 7,74 \\
\hline Треонин & $0,91 * * *$ & $-0,29$ & 6,41 & 1,61 \\
\hline Серин & $0,97 * * *$ & $-0,08$ & 7,29 & 0,12 \\
\hline Глутамат + глутамин & $-0,35$ & $-0,57 * *$ & 0,93 & 6,33 \\
\hline Пролин & $-0,69 * * *$ & $-0,64^{* * *}$ & 3,67 & 8,00 \\
\hline Глицин & $-0,90 * * *$ & 0,25 & 6,31 & 1,18 \\
\hline Аланин & $-0,44^{*}$ & $0,70 * * *$ & 1,49 & 9,65 \\
\hline Цитруллин & $-0,96^{* * *}$ & $-0,06$ & 7,09 & 0,07 \\
\hline Валин & $0,94^{* * *}$ & $-0,24$ & 6,79 & 1,10 \\
\hline Цистеин & $0,59 * * *$ & $0,67 * * *$ & 2,72 & 8,68 \\
\hline Метионин & $0,69^{* * *}$ & $0,56^{* *}$ & 3,64 & 6,05 \\
\hline Изолейцин & $-0,88^{* * *}$ & $-0,44^{*}$ & 5,98 & 3,84 \\
\hline Лейцин & $-0,93^{* * *}$ & 0,07 & 6,72 & 0,09 \\
\hline Тирозин & $0,80^{* * *}$ & $0,38^{*}$ & 4,90 & 2,87 \\
\hline Фенилаланин & $0,50 * *$ & $0,80^{* * *}$ & 1,95 & 12,37 \\
\hline Триптофан & $-0,83^{* * *}$ & 0,17 & 5,35 & 0,56 \\
\hline Орнитин & $-0,64^{* * *}$ & $0,64^{* * *}$ & 3,19 & 7,95 \\
\hline Лизин & $-0,81^{* * *}$ & $0,50 * *$ & 5,10 & 4,94 \\
\hline Гистидин & $-0,36$ & $0,91^{* * *}$ & 1,02 & 16,10 \\
\hline Аргинин & $-0,88^{* * *}$ & $-0,09$ & 6,03 & 0,17 \\
\hline
\end{tabular}

П р и м е ч а н и е. 1 - PC1, 2 - PC1 (главные компоненты, Principal Components; j = 1, 2). Собственные значения (eigenvalues, $\lambda_{\mathrm{j}}$ ) PC1 $=12,95, \mathrm{PC} 2=5,14$. Дисперсия, объясненная РС1, $-58,89 \%$, PC2 - $23,36 \%$. *, **, *** Статистически значимо соответственно при р $<0,05 ; \mathrm{p}<0,01$ и $\mathrm{p}<0,001$.

Нами выявлен сбалансированный полный состав незаменимых АК, отражающий качество среды обитания $H$. verbana в разные периоды жизненного цикла. К особенностям исследованных гирудинид относится оптимальный аминокислотный баланс, о чем свидетельствуют стабильные показатели критерия НАК/ЗАК в период раннего онтогенеза $(\mathrm{HAK} / 3 \mathrm{AK}=0,60)$ и у 9-месячных пиявок (НАК/3АК $=0,73)$.

В соответствии с имеющимися в литературе данными возрастная изменчивость аминокислотного обмена гидробионтов обусловлена их потребностями в приоритетных нутриентах, а аминокислотный состав тканей и органов объективно отражает физиологическое состояние особей на разных этапах биологического цикла $(1,6,10)$, что показано и в нашей работе.

Таким образом, существует тесная взаимосвязь между количественными и качественными показателями свободных аминокислот (АК) в тканях медицинских пиявок Hirudo verbana Carena, 1820 и темпом их роста и развития, что обусловлено многофункциональной ролью и степенью вовлечения АК в метаболические процессы формирования организма на разных 
стадиях онтогенеза. Информативность и адекватность изученных нами биохимических показателей физиологического состояния и адаптивных возможностей медицинских пиявок в условиях искусственного воспроизводства позволяет рекомендовать эти показатели для оценки физиологического статуса пиявки в гидрокультуре и в качестве готовой продукции, а также в условиях природной среды обитания. Это обстоятельство позволяет выдвинуть концепцию использования функциональных АК в качестве биомаркеров при разработке научных основ технологий промышленного разведения объектов аквакультуры. Экспериментальное подтверждение наличия полного и сбалансированного состава свободных АК в тканях медицинских пиявок служит дополнительным показанием к использованию их гомогенатов в медицине, фармацевтике и ветеринарии.

Авторы искренне признательны д.б.н. Г.И. Никонову за предоставленный биологический материал и поддержку при проведении исследований.

\author{
1 ФГБУН Институт экологии растений \\ и животных УрО РАН, \\ 620144 Россия, г. Екатеринбург, ул. 8 Марта, 202, \\ e-mail: kovalchuk@ipae.uran.ru $₫$, Chernaya_LV@mail.ru; \\ 2ФГБОУ ВО Уральский государственный \\ педагогический университет, \\ 620017 Россия, г. Екатеринбург, пр. Космонавтов, 26, \\ e-mail: mikshevich@gmail.com
}

Поступила в редакцию

30 ноября 2020 года

Sel’skokhozyaistvennaya biologiya [Agricultural Biology], 2021, V. 56, № 2, pp. 335-346

\title{
AGE DYNAMICS OF FREE AMINO ACIDS IN THE TISSUES \\ OF THE MEDICINAL LEECH Hirudo verbana Carena, 1820 \\ UNDER ARTIFICIAL REPRODUCTION IN AQUACULTURE
}

\author{
L.A. Kovalchuk ${ }^{1}$, L.V. Chernaya1 ${ }^{1}$ N.V. Mikshevich ${ }^{2}$
}

\begin{abstract}
${ }^{1}$ Institute of Plant and Animal Ecology, Ural Branch RAS, 202, ul. 8 Marta, Ekaterinburg, 620144 Russia, e-mail kovalchuk@ipae.uran.ru ( $₫$ corresponding author), Chernaya_LV@mail.ru;

${ }^{2}$ Ural State Pedagogical University, 26, pr. Kosmonavtov, Yekaterinburg, 620017 Russia, e-mail mikshevich@gmail.com ORCID:

Kovalchuk L.A. orcid.org/0000-0003-0467-1461 Mikshevich N.V. orcid.org/0000-0003-2388-4278

Chernaya L.V. orcid.org/0000-0002-3386-9824

The author declares no conflict of interests

Acknowledgements:

The authors are sincerely grateful to Dr. G.I. Nikonov for the biomaterial provided and the invaluable support in conducting these investigations.

This research has been carried out within the state assignment to the Institute of Plant and Animal Ecology (Ural Branch of the Russian Academy of Sciences, Yekaterinburg) and supported in part by the Presidium RAS, grant 12P-4-1049 ("Fundamental Sciences for Medicine").

Received November 30, 2020

doi: 10.15389/agrobiology.2021.2.335eng
\end{abstract}

\section{Abstract}

Medicinal leeches (Hirudo verbana Carena, 1820) used in veterinary medicine, human medicine and pharmacology, are currently bred artificially at bio-factories. The technology of leech culture as a component of aquaculture biotechnics is based on the method of accelerated growth of leeches due to intensive feeding, which allows you to get high-quality products in a fairly short time (8-10 months). Nevertheless, the problem of assessing the physiological status of raised individuals upon artificial reproduction remains not fully addressed. The findings we present herein for the first time allow us to suggest that the age-specific amino acid composition of tissues can be used to assess the physiological state and well-being of medicinal leeches in nature and in aquaculture. The aim of the work is to study the age-dependent content of the free amino acids in the tissues of medicinal leeches artificially bred in aquaculture. Studies were conducted in 2012 on the leech (Hirudo verbana Carena, 1820) individuals without signs of diseases which were purchased at the biofactory International Center for Medicinal Leeches (Moscow Province, p. Udelnaya). Leeches were kept in the laboratory in glass vessels with dechlorinated water at $20-22{ }^{\circ} \mathrm{C}$ and fed once a month with fresh bovine blood from healthy animals. The experimental specimens of $H$. verbana was: 5 days (newborn filaments, $0+$ ), 1 , 
3, 5, 7 and 9 months old, with an average body weight of $0.029,0.09,0.25,0.61,1.33$ and $1.81 \mathrm{~g}$, respectively. Newborn individuals served as a control. The concentration of free amino acids (AA) in the skin and muscle tissue was determined on the analyzer AAA-339M (Mikrotechna, Czech Republic). A total of 105 leech specimens were used, 30 bioassays were prepared, and 660 element determinations were performed. The amino acid composition of the tissues of medicinal leeches $H$. verbana was represented by $23 \mathrm{AA}$ and their derivatives. The dominant AA with an antioxidant orientation, regardless of age, were glutamine and glutamic acid, alanine, valine, leucine, and glycine, the total content of which was $65 \%$ in filaments, and $58 \%$ in 9 -month - old individuals of the total fund AA. In the tissues of medicinal leeches, as well as in warm-blooded animals, the full composition of essential amino acids (EAA) was revealed: threonine, valine, lysine, leucine, isoleucine, histidine, arginine, methionine, phenylalanine, tryptophan. With age, the total concentrations of free amino acids decreased $(r=-0.98$ at $\mathrm{p}=0.000)$, due to a sharp decrease in the content of arginine (24.0-fold), proline (13.4- fold), isoleucine (12.2- fold), glycine (8.5- fold), lysine (6.8- fold), histidine (6.6-fold), leucine (5.2-fold), ornithine (4.0-fold), glutamic acid and glutamine (3.8-fold), and alanine (2.9-fold). At the age of 5, 7 and 9 months, leeches had a trace content of secondary metabolites: taurine, citrulline and tryptophan $(\mathrm{p}<0.001)$. However, the amino acid balance of nitrogen and protein metabolism was not disturbed, since the ratio of essential / non-essential AA did not change significantly and was 0.60 in newborn filaments, $0.73-$ in 9 -month-old leeches. It was found that the growth and development of $H$. verbana was accompanied by a significant decrease in the indicator of maturity (glycine/alanine) from 0.75 (newborn filaments) to 0.25 ( 9 months). The information available in the literature and the data of our research allow us to put forward the concept of using functional amino acids as biomarkers in the development of the scientific bases of technologies for the industrial breeding of these amphibionts.

Keywords: medicinal leeches, leech culture, free amino acids, age, physiological status.

\section{R E F E R E N C E S}

1. Biological indicators of aquatic ecosystem stress. S.M. Adams (ed.). American Fisheries Society, Bethesda, Maryland, 2002.

2. Hochachka P.W., Somero G.N. Biochemical adaptation: mechanism and process in physiological evolution. Oxford University Press, New York, 2002.

3. Wu G. Amino acids: metabolism, functions, and nutrition. Amino Acids, 2009, 37(1): 1-17 (doi: 10.1007/s00726-009-0269-0).

4. Storey K.B., Storey J.M. Biochemical adaptation to extreme environments. In: Integrative physiology in the proteomics and post-genomics age. W. Walz (ed.). Humana Press, 2005: 169-200 (doi: 10.1385/1-59259-925-7:169).

5. Kovalchuk L.A., Mishchenko V.A., Mikshevich N.V., Chernaya L.V., Chibiryak M.V., Yastrebov A.P. Free amino acids profile in blood plasma of bats (Myotis dasycneme Boie, 1825) exposed to low positive and near-zero temperatures. Journal of Evolutionary Biochemistry and Physiology, 2018, 54(4): 281-291 (doi: 10.1134/S002209301804004X).

6. Ventura M. Linking biochemical and elemental composition of freshwater and marine crustacean zooplankton. Marine Ecology Progress Series, 2006, 327: 233-246 (doi: 10.3354/meps327233).

7. Guisande C., Riveiro I., Maneiro I. Comparisons among the amino acid composition of females, eggs and food to determine the relative importance of food quantity and food quality to copepod reproduction. Marine Ecology Progress Series, 2000, 202: 135-142 (doi: 10.3354/MEPS202135).

8. Brucet S., Boix D., López-Flores R., Badosa A., Quintana X.D. Ontogenetic changes of amino acid composition in planktonic crustacean species. Marine Biology, 2005, 148(1): 131-139 (doi: 10.1007/S00227-005-0068-4).

9. Evdokimov V.V., Matrosova I.V. Tikhookeanskii meditsinskii zhurnal, 2014, 1(55): 48-51 (in Russ.).

10. Golovina I.V., Gostyukhina O.L., Andreenko T.I. Rossiiskii zhurnal biologicheskikh invazii, 2016, 9(1): 53-66 (in Russ.).

11. Chernaya L.V., Koval'chuk L.A. Vestnik Orenburgskogo gosudarstvennogo universiteta, 2008, 10(92): 225-229 (in Russ.).

12. Chernaya L.V., Kovalchuk L.A., Nokhrina E.S. Role of the tissue free amino acids in adaptation of medicinal leeches Hirudo medicinalis L., 1758 to extreme climatic conditions. Doklady Biological Sciences, 2016, 466(1): 42-44 (doi: 10.1134/S0012496616010129).

13. Boëchat L.G., Adrian R. Evidence for biochemical limitation of population growth and reproduction of the rotifer Keratella quadrata fed with freshwater protest. Journal of Plankton Research, 2006, 28(11): 1027-1038 (doi: 10.1093/plankt/fbl036).

14. Peres H., Oliva-Teles A. Effects of the dietary essential to non-essential amino acid ratio on growth, feed utilization and nitrogen metabolism of European sea bass (Dicentrarchus labrax). Aquaculture, 2007, 267(1-4): 119-128 (doi: 10.1016/j.aquaculture.2007.01.010). 
15. Portella M.C., Tacata R., Leitão N.J., Menossi O., Kwasek K., Dabrowski K. Free amino acids in Pacu, Piaractus mesopotamicus, eggs and larvae. Journal of the World Aquaculture Society, 2013, 44(3): 425-434 (doi: 10.1111/JWAS.12034).

16. Song Z., Wang J., Qiao H., Li P., Zhang L., Xia B. Ontogenetic changes in digestive enzyme activities and the amino acid profile of starry flounder Platichthys stellatus. Chinese Journal of Oceanology and Limnology, 2016, 34(5): 1013-1024 (doi: 10.1007/s00343-016-5031-3).

17. Osako K., Kurokawa T., Kuwahara K., Nozaki Y. Seasonal variations in taurine and histidine levels of horse mackerel caught in the East China Sea. Fisheries Science, 2004, 70(6): 1180-1182 (doi: 10.1111/j.1444-2906.2004.00922.x).

18. Parvathi K., Karthegaa J. Influences of isolated probiotics on amino acid profile of fresh water fish Cyprinus carpio. International Journal of Recent Scientific Research, 2017, 8(11): 12417-12419 (doi: 10.24327/ijrsr.2017.0811.1070).

19. Karanova M.V. Rossiiskii fiziologicheskii zhurnal im. I.M. Sechenova, 2017, 103(1): 89-97 (in Russ.).

20. Baskova I.P., Kharitonova O.V., Zavalova L.L. Biomeditsinskaya khimiya, 2011, 57(5): 511-518 (doi: 10.18097/pbmc20115705511) (in Russ.).

21. Abdisa T. Therapeutic importance of leech and impact of leech in domestic animals. MOJ Drug. Des. Develop. Ther., 2018, 2(6): 235-242 (doi: 10.15406/mojddt.2018.02.00068).

22. Kustov S.Yu., Gorbunova Yu.K., Vardo L.E. Trudy Kubanskogo gosudarstvennogo agrarnogo universiteta, 2014, 48: 69-72 (in Russ.).

23. Ceylan M., Küçükkara R., Akçimen U., Çetinkaya O. Reproduction efficiency of the medicinal leech Hirudo verbana Carena, 1820. Turkish Journal of Fisheries and Aquatic Sciences, 2015, 15(1): 417-424 (doi: 10.4194/1303-2712-v15_2_27).

24. European convention on protection of the vertebrate animals used for experiment or in other scientific purposes (Strasbourg, on March, 18th, 1986). Available: https://www.coe.int/en/web/conventions/full-list/-/conventions/rms/090000168007a67b. No date.

25. Yarri D. The ethics of animal experimentation. Oxford University Press, New York, 2005.

26. Chessel D., Dufour A.B., Thioulouse J. The ade4 package-I: One-table methods. R News, 2004, 4: $5-10$

27. Love R.M. The chemical biology of fishes. London, New York, 1980. 